\title{
INDUSTRY REVOLUTION 4.0: STRENGHTHENING THE CREATIVE ECONOMY SECTORS THROUGH BEKRAF IMPLEMENTATION PROGRAMS
}

\author{
I Wayan Aditya Harikesa
}

\begin{abstract}
President Joko Widodo or Jokowi has made a great leap in enhancing Indonesia's Small Medium Enterprises (SME)s and the country's overall creative industries by establishing a new non ministerial institution called Badan Ekonomi Kreatif (BEKRAF) or the Creative Economy Agency. The BEKRAF, established under the Presidential Regulation Number 6 of 2015 issued on January 20, 2015, is responsible for accelerating the development of creative economy in Indonesia. Small Medium Enterprises (SMEs) have been playing crucial roles for generating economic progresses as well as social inclusion in Indonesia. Among the most important and worthy of priority is the country's creative economy. The existence of BEKRAF will enhance close cooperation between the government, SMEs players and related economic stakeholders. This paper aims to assess the concept of "Creative Industries," as a boundary concept that allows for increased co-operation between players and the generally opposing knowledge concepts-as reflected in their respective knowledge and cultural politics. Indonesia has great potential in terms of economic growth. In 2015, Indonesia's Gross Domestic Product (GDP) rocketed to 4.79 percent, far above the previous expectation of only 2.4 percent. This encouraging climate is indeed the right moment for the government to strengthen the country's economic foundation particularly in the real economic sector. Hence, BEKRAF has a vision to build Indonesia as one of the world's great economic powers in the field of creative economy by 2030. This issue will be discussed comprehensively in the final part of the paper.
\end{abstract}

Keywords: BEKRAF, Creative Industries, Creative Economy

\section{Introduction}

This paper, however, is inspired by the works of three theorists, Joseph Schumpeter, Theodore Adorno and Max Horkheimer, which reflects a conceptualization of knowledge and culture that aimed at preserving and fostering localized, cultural diversity, autonomous forms of cultural 
production and free cultural expression (Horkheimer and Adorno, 2006: 128). Contrary to Adorno and Horkheimer's critique of 'cultural industry', 'creative industries' and 'creative economies' are regarded here as a positive contribution to economic growth rather than the democratic replacement of totalitarian propaganda. Nevertheless, the terms 'creative destruction' (as stated by Joseph Schumpeter) involves both the mayor and minor cultural aspects of Indonesian people, especially young people in terms of economic, social, politic, technological as well as their lifestyle.

This paper comprises of three parts. The readers should understand the terminological use and attached definitions of the notions of 'creative economy' in Indonesia and BEKRAF program to enhance the creative economy sectors in Indonesia.

The first part of this paper aims to introduce the readers about the development of creative economy in Indonesia perspectives. All efforts and definitions about the creative economy will be discussed in this part in order to provide knowledge and understanding of the unique aspects of creative economy that has been developed in Indonesia.

The second part will touch on theoretical perspectives. This part contains theoretical works on boundary objects, tools, settings and concepts that theoretically underpin the study. Based on this factors I propose to reconceptualize 'creative industries' as a boundary concept which facilitates communication and co-operation between players with widely differing conceptualization of knowledge and culture. Also this part of the paper will focus on the works of Schumpeter's creative destruction theory in which create the renewal of 'old technology' into 'new technology'. Through Schumpeter's theory, we also study and explore about the reconceptualization of the market, the market we know has already transformed and over time and space boundary.

The final part of this paper will expose BEKRAF as a vessel of creative economy that has the purpose to fostering the Indonesian economic. In order to enhance the creative economy sectors, BEKRAF has a specific 
strategic plan to support the SMEs to be strong and independence and are able to excel in global market competition. In a wider perspective, BEKRAF has a quite ambitious dream to lead Indonesia as a big power in the field of creative economy within the South East Asia region. This will be explained further in this part of this paper.

Methodologically, this paper is based on (a) a qualitative method by gathering the data from books, international journals, formal website of government institutions that are related to the paper's topics, (b) qualitative methods by analyzing and processing the data by using the qualitative research software such as Mendeley and NVivo, and (c) qualitative expert interviews with representatives of government administrative bodies and especially with the representatives from BEKRAF, conducted in Jakarta 2019.

\section{The Rise and Culture of Indonesia's Creative Economics}

The term creative economics in Indonesia has been developed since it became the world phenomenon in 1990's in new economic sector. During this period, many heavy industry companies engaged in the automotive, health, food, technology and natural resources sectors requires great capital and at the same time a vast amount of labor. ${ }^{2}$ In other words, this situation had been slowly killing the heavy industrial companies such as Toyota, Honda, Volkswagen, Shell, Pertamina, Chevron, Nestle, and others (Forbes website, 2020).

The impact that arises as a result of this "wave change" phenomenon is the emergence of greater competitiveness or market competition. In order to challenge the market, this condition requires some companies to find ways to reduce costs as cheaply as possible and at the same time, as

\footnotetext{
2 To be noted, the heavy industry companies also suffer in area of internal affairs such as finance, recruitment process, management, and human resources respectively. Also, according to the Forbes Magazine, some companies have a difficult situation in terms of market penetration and competition among the similar sector. Forbes Magazine, 2019, https://www.forbes.com/global2000/list/5/\#tab:overall, accessed on 13 April 2019.
} 
efficiently as possible in order to maintain their existence. Industrialization creates three main parts such as pattern of work, production patterns, and distribution patterns that cheaper and more efficient.

Nowadays, we are witnessing the rapid emergence of the Internetbased companies in diverse sector, particularly in services and goods sectors. There are a number of successful Internet-based companies such as Go-Jek and Grab in transportation sectors. In retail sectors, we recognize popular companies such as Bukalapak, Tokopedia, Blibli.com and many others. This Internet-based emerging company has widely opened limitless opportunities for entrepreneurs to create and to secure new markets.

Developed countries are beginning to realize that they could not rely solely on industry as a priority in economic source or sector. Thus, they are starting to rely more on creative human resources because human creativity comes from their thinking, which is the basic capital to create innovation in the face of greater competitiveness or market competition. Therefore, in 1990's the new economic era began in which prioritized in area of information and creativity and was popularly known as the Creative Economy driven by an industrial sector called the Creative Industry.

The first wave of term in creative economic has been used and coined by John Howkins through his famous book "Creative Economy: How People Make Money from Ideas" in 2001. Howkins defines creative economy as an economic activity where the input and output are ideas. So it can be imagined that only with the capital of ideas, someone who is creative can earn relatively high income. Thus, creative economy as a concept means that to realize sustainable economic development based on creativity. The Utilization of resources that are not only in renewable conditions, but we can say unlimited, namely ideas, concepts, talents, and creativity itself (John Howkins, 2001).

The economic value of product or service in creative economic is no longer determined by raw materials or production system as in the industrial era. Rather, it is based on the use of creativity and the creation of 
innovation through increasingly advanced technological developments. Industry could no longer compete in the global market by only relying on products price or quality, on the contrary, they must compete based on innovation, creativity and imagination.

Prior to the concept of creative economy, in 1994, the term 'creative industries' had appeared in "Creative Nation", a report issued by the government of Australia. However, this term began to lift in 1997 when the United Kingdom Department of Culture, Media and Sport (DCMS) founded the Creative Industries Task Force. DCMS defines the creative industries as follows (Creative Industries Taskforce, 1998):

Creative Industries as those industries which have their origin in individual creativity, skill and talent, and which have a potential for wealth and job creation through the generation and exploitation of intellectual property and content. ${ }^{3}$

Based on DCMS definitions about the creative industries, the government of Indonesia used this as a reference to the definition of creative industries in Indonesia as written in the 2009-20015 Indonesian Creative Economy Development Plan Book issued by the Indonesian Ministry of Trade (2008) as follows (Agus Pascasuseno, 2008):

Creative Industries that originate from the use of creativity, skills and individual talents to create welfare and employment through the creation and utilization of the individual's creative and creative power.

In Indonesia, the creative economics has been developed and beginning to famous since 2005. The current president, Mr. Susilo Bambang Yudhoyono together with Indonesian Ministry of Trade, Dr. Mari Elka Pangestu stated about the importance of developing industry in a sector that is based on national craft and creativity. Thereafter, in 2006, Dr.

\footnotetext{
${ }^{3}$ From the mid-1990s onwards, numerous governments worldwide rediscovered the economics of creativity and culture. In 1998, the UK Creative Industries Taskforce published its 'Creative tries mapping document', which later also influenced Singapore's respective policymaking. See Creative Industries Taskforce, Creative industries mapping document (London: Department Culture,

Media

and

Sport, 1998).
} 
Mari Elka Pangestu launched the Indonesia Design Power program within the ranks of the Indonesian Ministry of Trade. This program is a government-level program that is expected to increase the competitiveness of Indonesian products in the domestic and foreign markets (Mari Elka Pangestu, 2008).

The Indonesian Design Power program focuses on developing the service sector, and can provide space for creative actors and industries. Afterwards, the term creative economy and creative industry began to be discussed frequently by the people of Indonesia. Today, Indonesia is facing the same problem as any other developed countries in terms of creative economics. Nevertheless, I humbly raise a notion that, the government of Indonesia should take this as an opportunity. Unlike the under-developed country such as countries situated in the part of middle African region or even some countries located in The South East Asia, creative economic could be the "gold mine" for Indonesia in terms of finding a new emerging markets, particularly it would enhance the Indonesian GDP (Gross Domestic Products) significantly.

This favorable economic situation was affected by the development of technological advancement as well as the Internet penetration level in Indonesia. The high-level of Internet penetration has changed the way of Indonesia people to find the best solution in their respective economic areas. In today technology, not surprisingly, there is many potential market that can be explored. Unlike the traditional market, the non-traditional market and contemporary market could drive some SME's to take part in it.

During the rising of creative economic, the Indonesian government identified the scope of creative industries covering 16 sub-sectors, as follows by the order in which the most contributing in terms of enhancing Indonesia GDP (Badan Ekonomi Kreatif Indonesia, 2019):

Table 1.0

16 Sub-Sector of Creative Economic 
Towards GDP per 2018

\begin{tabular}{llc}
\hline No. & Sub-Sectors of Creative Economic & $\begin{array}{c}\text { GDP Contribution } \\
\text { (In percent) }\end{array}$ \\
\hline 1. & Culinary & $41.69 \%$ \\
\hline 2. & Fashion & $18.15 \%$ \\
\hline 3. & Craft & $15.70 \%$ \\
\hline 4. & Television \& Radio & $7.78 \%$ \\
\hline 5. & Publishing & $6.29 \%$ \\
\hline 6. & Architecture & $2.30 \%$ \\
\hline 7. & Application \& Game Developer & $1.77 \%$ \\
\hline 8. & Advertising & $0.80 \%$ \\
\hline 9. & Music & $0.47 \%$ \\
\hline 10. & Photography & $0.45 \%$ \\
\hline 11. & Performing Arts & $0.26 \%$ \\
\hline 12. & Product Design & $0.24 \%$ \\
\hline 13. & Arts & $0.22 \%$ \\
\hline 14. & Interior Design & $0.16 \%$ \\
\hline 15. & Film & $0.16 \%$ \\
\hline 16. & Visual Communication Design & $0.06 \%$
\end{tabular}

Source: Data Statistik dan Hasil Survei Ekonomi Kreatif, Badan Ekonomi Kreatif Indonesia (http://www.bekraf.go.id/pustaka/page/data-statistik-dan-hasil-survei-khusus-ekonomikreatif), accessed on 13 April 2019.

Based on the table, the top three amongst the 16 sub-sectors of creative economic in Indonesia are culinary, fashion and craft sectors contributing at each other 41.69, 18.15 and 15.70 percent respectively. These three sub-sectors form a uniqueness of Indonesian creative economic that will distinguish from other countries. The culinary sub-sectors contribute a vast culinary types and tastes from 34 provinces in Nusantara, (Archipelago). Each province has a different local culinary, which is famous both in types and tastes, this potential creative economic market has a distinguish uniqueness from other countries. In West Sumatra, for instance, we know Rendang (spicy beef) has been crowned as one of the world's best food. Creative people may explore this cuisine into high dining to appeal to international demand. Meanwhile, Indonesia has thousands of appetizing 
cuisines from across the country, and therefore the economic potentials will be tremendous.

At the same time, both in fashion and craft sub-sectors also contribute a significant value for Indonesia GDP. Indonesia is famous for the varieties of it local wisdom and local culture stretch from Aceh Province into Papua Province. For instance, regarding with fashion sub-sector, many consumers or tourists will find many different types of traditional Batik in Java Province, or traditional Endek fabric in both Bali and East or West Nusa Tenggara Province. In addition, through fashion and textile industry, Indonesia's batik has been regarded as UNESCO's world heritage. The country has hundreds of types of traditional textiles with bold and beautiful patterns. These local textiles can be tailored as high-end fashion items that will add their economic values. Not to mention other sectors such as crafts, music and architectural products.

BEKRAF functions as a vessel of creative economy in Indonesia. The agency has been active in supporting the country's creative economy by encouraging Small Medium Enterprises (SMEs) players and other stakeholders to engage in a new concept of industrial revolution. BEKRAF has been fostering SMEs to create unique products that have distinctive characteristic of Indonesian culture.

In an interview with Dr. Hari Sungkari, Deputy of Infrastructure of BEKRAF, he underlined the importance of SMEs to understand four crucial factors that can accelerate their businesses in the emerging markets of creative economy. Dr. Sungkari added that SMEs must understand the values of local wisdom and local culture, invention, innovation and good packaging. The factors, he said, will distinguish the uniqueness of Indonesian creative economy from other countries.

Dr. Sungkari added Indonesia has enormous cultural and traditional wealth. The country has 17,000 islands with hundreds of different ethnicities, each has its own distinguish culture and tradition. Citing an example, in culinary sectors, Indonesia has thousands of food specialties 
that can generate huge economic potential. Exploring the beauty of local culture and local wisdom to create distinctive products, Indonesia will stand tall on the global economic market.

\section{Re-conceptualization of Creative Economics}

This part discusses some of the foundations theory of a digital labor theory of value. Also, this part become a fundamental aspect to understanding the boundary of creative economy, tools, settings and concepts respectively. Therefore, for us, the people who are living in the $21^{\text {st }}$ century, these concepts should be embedded in our minds and thoughts to reconsider the changing phenomena of locus and nexus of the new emerging markets.

In this modern day capitalist, the duality concepts of time and space have been transformed into what we called 'limitless'. It is simple because both of them do not have any limitation regarding to where and when the situation is happening. For the concept of time itself, according to the Hegel, he argues that time is a fundamental aspect of matter. "In time, it said, everything arises and passes away, or rather, there appears precisely the abstraction of a rising and falling away" (Hegel in Marxist web, 2019).

Nevertheless, I found a series of connection between the Hegel thought and the 'relativity theory' by Professor Albert Einstein. I humbly suggest that Hegel propose the concept of time to be understanding as a specific matters of momentum. However, in order to create the exact momentum, it still need of excess of force or a power. In capitalism, it can be found at the drive of the needs of the labor. Labor is an essential factor in order to move the wheel of capitalism. Without the labor power in every industries and economics, I believe that no industry could run properly.

Also, if we look at the momentum, time plays a significant role in the form of labor time, reproductive labor time, struggles over the working day, absolute and relative surplus-value production that is based on a dialectic of labor and time respectively (Horkheimer 1994, Adorno 2004: 18). 
Thus, the concept of time in capitalism develops into further and have been evolving. Based on the Christian Fuchs works, Digital Labour and Karl Marx (Fuchs, 2014: 22). Fuchs (2014) offered a simple minded concept of time in his assumption in digital labour. Fuchs argues that in the capitalist and it relation of time, all the factors that accelerate the profits of some industry, it need to re-conceptualize such as the factor of creation or production, circulation and consumption, the acceleration of finance, temporal fixes to crises of capital accumulation respectively. It is very simple to say that in creative economy and creative industry, the productive labor that enhances the time production is necessary.

The emergence of social media in today digital era is one of the expressions of the contradiction between time and traditional capitalism. Corporates that have been works under the internet-based, are spaces for exploitation of new forms of surplus labor under capitalist conditions. They are at the same time forms a society, in which necessary labor time is minimized, surplus labor time abolished and creative activities shape human lifetime.

The rise of capitalist social media corporations such as Facebook, Twitter, YouTube, etc. has not been rendered the concepts of labor time and the law of value superfluous. However, it is an expression of new qualities of the labor theory of value. The more time a user spends on Facebook, the more profile, browsing, advertising, communication, behavioral, content data that the user generates. Their time concept was transformed into a new commodity in capitalism to advertising clients. In other way, the more time a user spends online, the more targeted ads can be presented to her or him.

In terms of wageworkers in traditional Marxist capitalism, or in the non-digital economy are seen as the true locus of power. Therefore, it needs a recommended political measure to be taken focus on how to organize these workers or labors in unions, parties or other organizations and struggles for higher wages and better wage labor conditions (Karl Marx, das capital, 1894). Hence, Christian Fuchs (2014: 12) provided the three main 
matters of productive labor (1), (2), (3), as I will quote from his book, Marx in the Age of Digital as following:

1. Productive Labor (1): Work that produces the use-values

2. Productive Labor (2): Labor that produces capital and surplusvalue for the purpose of accumulation

3. Productive Labor (3): Labor of the combined or collective worker, labor that contributes to the production of surplus-value and capital

As mention by Christian Fuchs, the one to be remembered in relation of time and modern capitalism is productive labor. These driven because of knowledge is a peculiar commodity that can quickly be copied and does not disappear by all these following aspects such as consumption, which does, however, not mean that its producers are unproductive. Therefore, the second concept of space has been re-conceptualize.

However, before we discussed about the space concepts that have been re-conceptualize in capitalism, let take a short brief about the development of creative industries. Since the mid-1990s, a continuously growing number of national governments, their policy-producing bodies, multilateral organizations and civil society representations around the world have released policies, programs and initiatives to promote 'creative industries'. Connecting to the industry revolution 4.0, The United Nations Educational, Scientific and Cultural Organizations (UNESCO), together with the Global Alliance for Cultural Diversity, states that 'creative industries are becoming increasingly important components of modern post-industrial knowledgebased economies' (UNESCO and Global Alliance, 2019).

These relatively fuzzy concept encourages recognizable action worldwide, Indonesia is no exception, although it should be noted that the precise definitions implied and the interests or rationale behind using the concept vary widely.

One of the supporters of the concept of 'creative industries', John H. Hartley mentions that the creative industries idea varies geographically, 
depending on local heritage and circumstance. Most notably, in the United States, creativity is consumer - and market-driven, whereas in Europe it is caught up in the traditions of national culture and cultural citizenship (Hartley, 2005: 10).' John Howkins also rising a points out that (Howkins, 2001: 4):

Most countries would agree that creativity and its industries embrace the creative imagination in all its forms. But a few, including Britain and Australia, restrict the term "creative industries" to the arts and cultural industries and exclude science and the patent industries.

This example of the term 'creative industries' has been rising in the big-industrial countries such as United States of America, Britain and Australia. Nevertheless, the prior chapter of this paper already explained explicitly that the Indonesian creative industries and creative economies has its own uniqueness. However, to define and to highlight the similarities the terms 'creative industries', most academics agreed to the what Hartley argued. The creative industries and creative economics need a specific 'vessel' and 'soil' to grow. It depends on 'its vessel and its soil to grow'. Let takes an example of the Japanese capitalism culture, since the Meiji era in Japan it is worldwide known that capitalism has growth very-rapidly. But, the Japanese did not just get rid of its fascinating culture, however, the value of capitalism and Japanese culture fuses at each other and flourish in Japan and even create a new capitalism culture eventually.

The Japanese culture gives us an example about how the aspect of space working in capitalism, particularly in creative economic. Thus the aspect of space is really important not only in geographically but also we need to consider this concept has expanse broadly. These are including: the new and emerging market, workplace for labor, capital and profits, the new alternative business sector and technology embeddedness. Hence, loosely 
defined terms and concepts, leave space for creative exploration, while tight definitions close off this space.

This suggest that it is useful to frame the terms 'creative economic', 'creative industries' and the other terms that using the creative concept. The creative term developed by Löwy (1992: 371-96), and this concept was taken up and developed further by Peter Mollinga (2010: 12-14). In his boundarycrossing framework - and relates to the development of interdisciplinary research and work, Mollinga relates Löwy's thoughts on 'boundary concepts' to the notion of 'boundary objects', as grasped by Susan Leigh Star and James R. Griesemer, and complements both by adding the notion of 'boundary objects' (Leigh 1989, Griesemer 1989: 387). Therefore, these three notions 'boundary concepts', 'boundary objects' and 'boundary settings' respectively became the embodiment of creative economics. These three notion are identified by Mollinga (2010) as the three pillars of his boundarycrossing framework, the main value of which he sees in its ability to 'rationalize dissent'. As Mollinga states,

[...] boundary concepts are words that operates as concepts in different disciplines or perspectives, refer to the same object, phenomenon, process or quality of these, but carry (sometimes very) different meanings in those different disciplines or perspectives. In other words, they are different abstraction of the same "thing".

These notions are reaffirmed as 'boundary concept' stands in close proximity to 'boundary objects', defined by Star and Griesemer as follows:

[...] both plastic enough to adapt to local needs and the constraints of the several parties employing them, yet robust enough to maintain a common identity across sites. They are weakly structured in common use, and become strongly structured in individual site use. ${ }^{4}$

4 The quote continues: These objects may be abstract or concrete. They have different meanings in different social worlds but their structure is common enough to more than one world to make them recognizable, a means translation. The creation and management of 
Löwy, nevertheless, stresses an important commonality between ‘boundary objects' and ‘boundary concepts' (Ilana Löwy, 1992: 371-96):

Both 'boundary concepts' and 'boundary objects' are multifunctional: on the cognitive level they make possible the interaction of distinct scientific cultures and thus permit the construction of a given segment of knowledge, while on the social level they facilitate the development of inter-group alliances and therefore advance specific social interests. ${ }^{5}$

Thus, in order to discuss the creative economic further, I humbly suggest that three concepts; 'boundary concepts', 'boundary objects' and 'boundary settings'; are needed to distinguishing from the other economic sector terms such as industrial economic, political economic, cultural economic, etc. In other words, the concept of space are the spaces, conducive, enabling environments or settings where these 'concepts, devices and methods can be fruitfully developed and effectively put to work' (Peter Mollinga, 2008: 12-14).

\section{BEKRAF Implementation Programmed in Creative Economic}

This part of the paper is about the Creative Economy Agency - Badan Ekonomi Kreatif (BEKRAF) implementation programmed. This part is mostly showing BEKRAF functions as a vessel of creative economy in Indonesia. The agency has been active in supporting the country's creative economy by encouraging Small Medium Enterprises (SMEs) players and other stakeholders to engage in a new concept of industrial revolution. BEKRAF

boundary objects is a key process in developing and maintaining coherence across intersecting social world'. In Star and Griesemer, 'Institutional ecology, "translations" and boundary objects', p. 393.

${ }^{5}$ Löwy, 'The strength of loose concepts', pp. 374-5. Here, Löwy also distinguishes between 'boundary objects' and 'boundary concepts' by stressing: "Boundary objects" are composed of a "hard core" - the zone of agreement between interacting professional groups - and of a "fuzzy periphery" which is different for each of these groups. "Boundary concepts" ("ideal types") are loosely defined concepts which, precisely because of their vagueness, are adaptable to local sites and may facilitate communication and cooperation.' 
has been fostering SMEs to create unique products that have distinctive characteristic of Indonesian culture.

Thus, related to this paper and research, I would like to show graphically BEKRAF strategic plan during 2015-2019 in fostering creative economic sector, why I consider this year in my paper? The first reason is because during this year, Indonesia experienced the rise of enormous in term of creative economics in many ways. The second is by 2015, Indonesia has already entering many regional market cooperation frameworks such as The ASEAN Free Trade Area (AFTA) and ASEAN Economic Community (AEC) - by that means everyone from all over the world have the same opportunity to work in other countries and increasing the competitiveness in many strategic sectors such as economic sector in terms of workplaces and jobs.

Since the high internet penetration among Indonesia people in this global technology era, it has experience some shifting in their mind and "how everything is works", in other words, the "old-fashioned" pattern of their life has changing drastically. One can be remembering was starting by 2010 through the establishing of PT Aplikasi Karya Anak Bangsa by Nadim Makarim as a founder and both Michaelangelo Moran and Kevin Aluwi as a co-founder, the company then famous by the name G0-JEK. GO-JEK is one of the creative economic company that using the internet-based in running properly through application that can be downloaded from Android Google Play Store and integrated via smart-phone users.

However, I would not have discussed about GO-JEK any further in this paper, but I would like to raise another notion about this kind of creative economic needs institution framework that can be provided the creative economy players in terms of such as: i) Superstructure and Infrastructure building needs to tent all the system in running properly such as establishment of facility buildings and to create the "balance" business ecosystem; ii) Law protection necessary to avoid the "ideas piracy" through the creation of Intellectual Copyright Law of the Republic of Indonesia (UU Republik Indonesia, Nomor 28 Tahun 2014 Tentang Hak Cipta); iii) 
Advocacy and training provide an in-depth understanding of products that have the potential in market and has local wisdom value; iv) Capital and investment driven attracts the foreign investors in accordance with the provisions of the Foreign Investment Law of the Republic of Indonesia (UU Republik Indonesia, Nomor 25 Tahun 2007 Tentang Penanaman Modal).

This would be the vocal point from the existences of BEKRAF itself. BEKRAF is present in the middle of growth of Indonesia creative atmosphere, as an institution, BEKRAF has a role to facilitate whole entrepreneurs which engaged in the creative industries sectors. Entrepreneurs will get a benefit by joining BEKRAF and get more opportunity in competitive market.

Thus, on January 20, 2015, the Indonesian government has placed creative economy as its priority by establishing the Creative Economy Agency - BEKRAF. By using the terms 'creative economy', the Indonesian government realizes that the country has great potential to boost its economic growth. In 2015, Indonesia's Gross Domestic Product (GDP) rocketed to 4.79 percent, far above the previous expectation of only 2.4 percent. This encouraging climate is indeed the right moment for the government to strengthen the country's economic foundation particularly in the real economic sector (BEKRAF Official Website, 2019).

BEKRAF has a strategic plan to enhancing the Indonesia's GDP significantly by looking at "demographic bonus" of Indonesia people. As stated prior, creative economic in Indonesia can flourish because of the unique vessels of the variety of culture in itself. However, by demographically, Indonesia has the opportunity to be able to enjoy the demographic bonus, in which, the acceleration of economic growth due to changes in the age structure of the population that is characterized by a decrease in the dependency ratio of non-productive workers to productive workers.

Thus, BEKRAF formulated a strategic plan in order to create the creative economic ecosystem and accommodated the creative workers. This 
become the core strategic for BEKRAF and stated three ultimate outcomes (impact) as follows: (1) increase the amount of companies; (2) increasing value added per companies; and (3) Indonesia's creative product become worldwide. From this three impacts would produce: increasing the creative economic GDP, creative product export, and increasing the creative workers. As stated in Figures 1.0 bellows:

Figures 1.0

BEKRAF Strategic PLAN in Macro Level

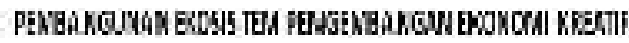

LITWTE WTWES SBDHANWW impthogse

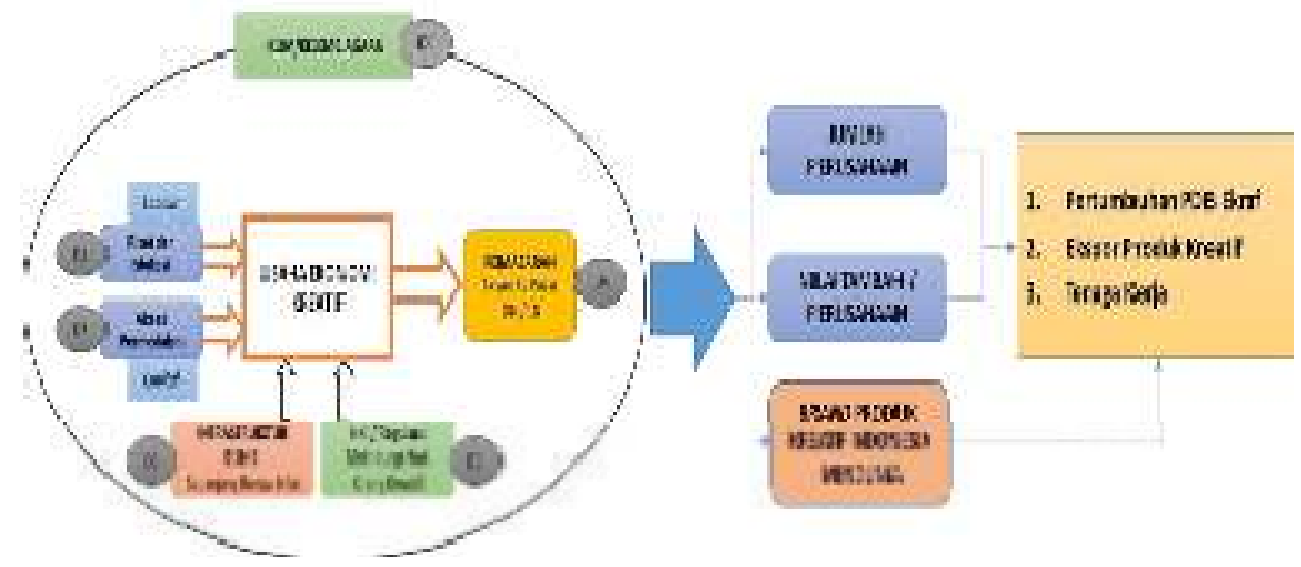

Source: Rencana Strategis Badan Ekonomi Kreatif,

(http://www.bekraf.go.id/pustaka/page/35-rencana-strategis-badan-ekonomi-kreatif2015-2019), accessed on 14 April 2019.6

BEKRAF oversees entrepreneurs in which engaged in sub-sectors of creative economics. According to the figure above, there are several goals for BEKRAF during 2015-2019. However, BEKRAF strategic goals adopted from National Medium-Term Development Plan (RPJMN) of Creative Economy Sector. With thus the formulation of the 2015-2019 BEKRAF Strategic Target is as following (Rencana Strategis BEKRAF 2015-2019: pp. 12):

${ }^{6}$ The figure I've been used on this paper based on the permission from BEKRAF, downloaded at: http://www.bekraf.go.id/pustaka/page/35-rencana-strategis-badan-ekonomi-kreatif-20152019, accessed on 14 April 2019, pp. 18. 


\section{Strategic Goal 1: Increasing the Growth of Creative Economic GDP}

The Strategic Target Performance Indicator - Indikator Kinerja Sasaran Strategis (IKSS) which is the creative economy GDP far above 6.75 percent in 2019.

\section{Strategic Goal 2: Workforce}

The Strategic Target Performance Indicator - Indikator Kinerja Sasaran Strategis (IKSS) which absorption of workforce with a target of 17 million people by 2019 .

\section{Strategic Goal 3: Export Value of Creative Product}

The Strategic Target Performance Indicator - Indikator Kinerja Sasaran Strategis (IKSS) which value of exports gross in Indonesian creative products with a target of USD 21.5 billion in 2019.

On the contrary of BEKRAF strategic implementation programs, there are number of obstacles need to be concern. First priority should concern the economic disparity become one of major challenge for Indonesian national development. Development inequality illustrate the biggest challenge for government of Indonesia, a large amount of poverty and vulnerability which is reflected by the declining poverty rate and the rate of employment, in which has not significantly reduced vulnerable workers. For this reason, the challenge of eliminating the development gap is that it can improve the living standards, starting from the 40 percent, and ensure that the underprivileged people could have access to social protection through the creation of inclusive growth.

However, the opponent of this view argues that in today globalization era we must make the best use of technology (Hari Sungkari, 2019). The benefit of integrated technology could be considering as an advantage. For instance, in most situations, we can use the smart-phone to find jobs that we wanted, or if we are entrepreneurs, we can place our products for selling in certain digital markets such as Tokopedia, Blibli.com, Bukalapak.com, 
Kaskus, and many others. Thus, with the emergence of new market hopefully it could minimalize these factor and also get the benefit from it, in addition it also can added a local wisdom value through their selling product.

In order to achieve these development goals, thus BEKRAF also added the direction of creative economic development policy to facilitate it actors along the value chain. Starting from the stages of creation, production, distribution, consumption, into conversation respectively. Moreover, creative economic ventures have the main characteristic of being moved by creative people who are generally young and not capital intensive ventures. I believed this is the main reason because it will open the widest possible opportunity to the community inclusively.

BEKRAF would involve whole creative economic actor under one roof system and mechanism. This strategy is meant to be to create a conducive ecosystem for creative industry entrepreneurs. This also related to BEKRAF's vision in which developing a creative economy into a new power of the national economy by constantly encouraging the progress of creative economic entrepreneurs. In order to realize it needs to: (1) all of the Indonesia's assets and creative potential need to be united to achieve an independent creative economy; (2) a conducive climate for development of creative industries needs to be built; (3) innovations in the creative field with added value and competitiveness in the international market need to be encouraged; (4) public insight and appreciation of all aspects related to the creative economy need to be opened; (5) awareness and appreciation of intellectual property rights, including legal protection of copyright needs to be built; (6) specific strategies to place Indonesia in road map of the world creative economy need to be designed and implemented (Rencana Strategis BEKRAF 2015-2019: pp.12).

BEKRAF commitment to bring Indonesia as a new power in creative economy reflected in the six elements above, thus it would bring a good and conducive ecosystem. A conducive ecosystem consists both of creative space 
and appreciative space. This however as stated in Strategic Plan of the Creative Economy Agency 2015-2019, as shown by the table below:

Table 2.0

Strategic Goals and Strategic Target Performance Indicators

\begin{tabular}{|c|c|c|c|c|c|c|}
\hline Strategic Goals (SG) & \multicolumn{5}{|c|}{ Target } & \multirow[t]{2}{*}{ Description } \\
\hline $\begin{array}{l}\text { The Strategic Performance } \\
\text { Indicator (SPI) }\end{array}$ & 2015 & 2016 & 2017 & 2018 & 2019 & \\
\hline \multicolumn{7}{|l|}{$\begin{array}{l}\text { SG 1: The Growth of } \\
\text { CreativeEconomic }\end{array}$} \\
\hline $\begin{array}{l}\text { SPI The growth of creative } \\
\text { economic }(\%)\end{array}$ & 4.38 & 5.21 & 5.70 & 6.25 & 6.75 & $\begin{array}{l}\text { Adjusting the RPJMN } \\
\text { target }\end{array}$ \\
\hline \multicolumn{7}{|l|}{ SG2:WorkforceAbsorption } \\
\hline $\begin{array}{l}\text { SPI Workforce absorption (in } \\
\text { million)people }\end{array}$ & 15.96 & 16.20 & 16.40 & 16.70 & 17.00 & $\begin{array}{l}\text { Sophisticated the } \\
\text { RPJMNtarget }\end{array}$ \\
\hline \multicolumn{7}{|l|}{$\begin{array}{l}\text { SG 3: Export Value of } \\
\text { CreativeProducts }\end{array}$} \\
\hline $\begin{array}{l}\text { SPI Gross export value } \\
\text { (billion USD) }\end{array}$ & 19.36 & 19.99 & 20.50 & 21.00 & 21.50 & $\begin{array}{l}\text { Modification the } \\
\text { RPJMN target }\end{array}$ \\
\hline
\end{tabular}

Based on the table above, there are an increasing number of target in terms of the growth of creative economic during 2015, 2016, 2017 and 2018 mentions in percentage by $4.38,5.21,5.70$, and 6.25 percent respectively. BEKRAF efforts in creative economic marked by the increasing number of entrepreneurs and SME's who are turning their respective business from traditional economic sector into creative economic sector. This condition also brings an impact in terms of workforce absorption, in relation with the growth of creative economic. The table shows us there are several increasing number of workforce approximately 16.4 million people in average in during 2015-2019 or equal to 1.5 percent increasing every year, it also has an impacts as well as in terms of gross export value as shown by table above. Despite the small percentage, however it still shown a significant mount in creative economic sector.

I would like to shown data explains BEKRAF intervention in its effort of growing creative economic GDP. Nevertheless, in economic sector, prior

7 Data and statistic has been processed on 15 April 2019, pp. 33. Courtesy of BEKRAF, 2019 
Indonesia has experience economic slowdown in 2011 due to global financial crisis in 2008. This serious situation has an impact in terms of economic sector as well as creative economic sector.

During four year terms, 2011-2015, Indonesia economic growth were falling down from 6.33 percent in 2011 into 4.38 percent. However, after 2015 , there is an increasing in creative economic sector, but this was not enough to be able to increase the contribution of the creative economy in the national economy, because its growth remained below the GDP growth. Therefore, special intervention is needed by BEKRAF so that creative economic growth can gradually be higher than GDP growth as shown by figure below:

\section{Figure 1.1}

\section{Creative Economic Growth 2011-2015}

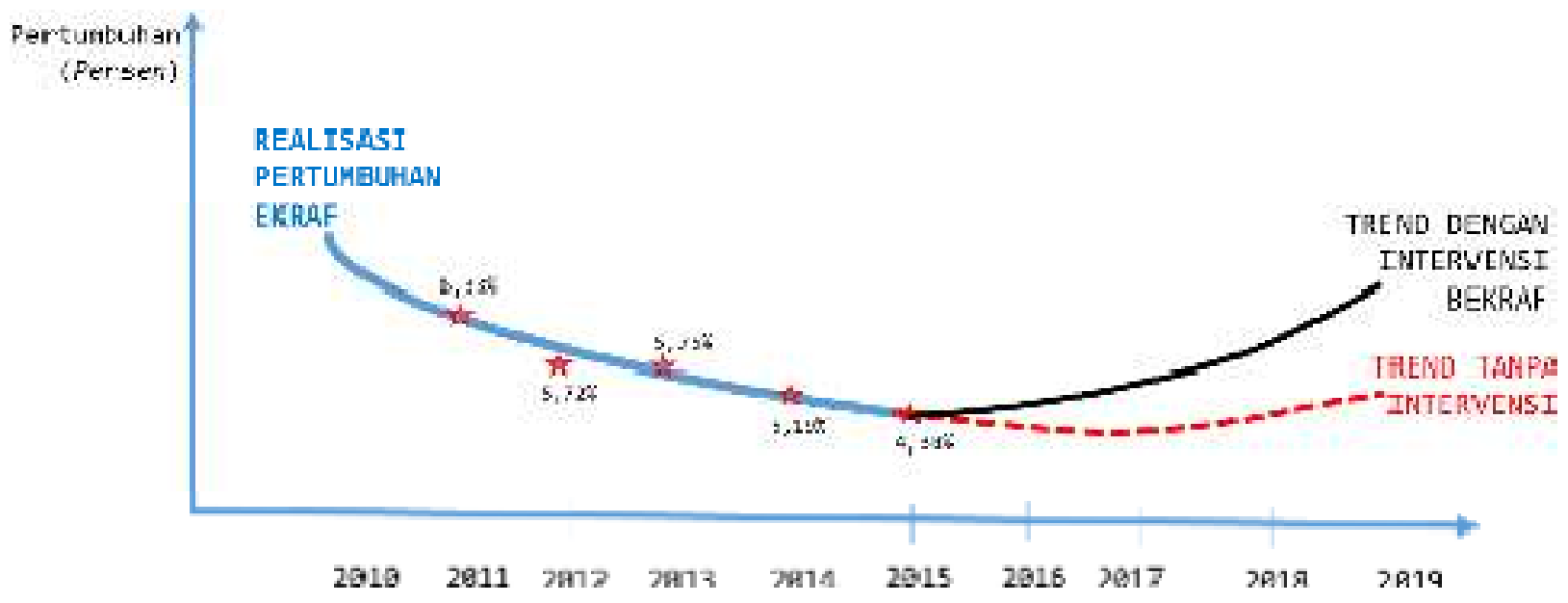

\section{Conclusion}

In Industrial Revolution 4.0, it seems that all countries are facing similar problem, including Indonesia. Indonesia The revolution itself took a concern on how the means of production and the production factor has been change since ten or twenty years ago. Many countries today have been struggle to prepare of that matter. It is said because, this phenomenon requires great amount of resources - human and natural resources, 
capitals, technologies, and a good government that support the revolution itself.

As it concerns, Indonesia has a potential to be the one as a pioneer in South East Asian regions, or in other words, amidst the ASEAN members. In my opinion, the key point to understand and be ready in Industrial Revolution 4.0 is the government must have an institution that integrated with all the new technology. Therefore, it requires all government sectors which can be embedded in one integrated system as well as have an institution that can be functioned as an implementation.

Thus, in this matter, BEKRAF as one of the government sector which tackle the issues of industrial matter in creativity sector. Creative industries are a spear point to enhance the development of small industries and integrating with a new technology. In order to achieve these development goals, thus BEKRAF also added the direction of creative economic development policy to facilitate it actors along the value chain. Starting from the stages of creation, production, distribution, consumption, into conversation respectively. Moreover, creative economic ventures have the main characteristic of being moved by creative people who are generally young and not capital intensive ventures.

BEKRAF would involve whole creative economic actor under one roof system and mechanism. This strategy is meant to be to create a conducive ecosystem for creative industry entrepreneurs. This also related to BEKRAF's vision in which developing a creative economy into a new power of the national economy by constantly encouraging the progress of creative economic entrepreneurs. In order to realize it needs to: (1) all of the Indonesia's assets and creative potential need to be united to achieve an independent creative economy; (2) a conducive climate for development of creative industries needs to be built; (3) innovations in the creative field with added value and competitiveness in the international market need to be encouraged; (4) public insight and appreciation of all aspects related to the creative economy need to be opened; (5) awareness and appreciation of 
intellectual property rights, including legal protection of copyright needs to be built; (6) specific strategies to place Indonesia in road map of the world creative economy need to be designed and implemented.

\section{REFERENCES}

Afif, Faisal. 2012. Pilar Pilar Ekonomi Kreatif. Artikel. Universitas Bina Nusantara: Jakarta.

Bekraf Official Website. (www.bekraf.go.id), accessed on 14 April 2019. Jakarta, 2019.

Elka, Mari Pangestu. 2008. Pengembangan Ekonomi Kreatif Indonesia 2025. Cetak Biru Ekonomi Kreatif: Departemen Perdagangan Republik Indonesia.

Fuchs, Christian. 2014. Digital Labour and Karl Marx. New York: Routledge. Fuchs, Christian. 2015. Culture and Economy in the age of Social Media. New York: Routledge.

Fuchs, Christian and Vincent Mosco, eds. 2016. Marx in the Age of Digital Capitalism. Studies in Critical Social Sciences, edited by David Fasenfest, Volume 80. Leiden: Brill.

Forbes website, The World's Largest Public Companies, website can be accessed on: https://www.forbes.com/global2000/list/5/\#tab:overall, accessed at April, 13, 2019.

Haug, Wolfgang Fritz. 1986. Critique of Commodity Aesthetics. Cambridge: Polity Press.

Hartley, John H. 2005. Creative Industries. Malden: Blackwell Publishing Ltd).

Hegel, Georg Wilhelm Friedrich. 1817. Encyclopaedia of the Philosophical Sciences. Part 2: Philosophy of Nature. 
http://www.marxist.org/reference/archive/hegel/works/na/naconte n.htm. Accessed on 13 April 2019.

Horkheimer, Max and Theodor W. Adorno. 1994/2002. Dialectic of Enlightenment. Philosophical Fragments. Stanford, CA: Stanford University Press.

Howkins, John. 2001. The Creative Economy: How People Make Money from Ideas. London, Allen Lane: The Penguin Press.

Karl Marx. 1894. Capital Vol. III. A Critique of Political Economy: Volume Three. London: Penguin.

Löwy, Ilana. 1992. 'The strength of loose concepts - Boundary concepts, federative experimental strategies and disciplinary growth: The case of immunology'. In History of Science, Vol. 30 (1992): 371-96.

Mollinga, Peter. 2008. The rational organization of dissent. ZEF Working Paper Series no. 33. Bonn: University of Bonn.

Mollinga, Peter. 2010. 'Boundary work and the complexity of natural resources management'. Crop Science, 50, 1 (2010): S1-S9. Peter Mollinga discusses 'water control' as a boundary concept in: Mollinga, Peter. 2008. For a political sociology of water resources management, ZEF Working Paper Series no. 31. Bonn: University of Bonn, pp. 1214.

Pascasuseno, Agus. 2014. Ekonomi Kreatif: Kekuatan Baru Indonesia Menuju 2025. Bedah Cetak Biru Ekonomi Kreatif: Yogyakarta.

Postone, Moishe. 1993. Time, Labor, and Social Domination. A Reinterpretation of Marx's Critical Theory. Cambridge: Cambridge University Press.

Postone, Moishe. 2003. The Holocaust and the trajectory of the twentieth century. In Catastrophe and Meaning. The Holocaust and the Twentieth Century, edited by Moishe Postone and Eric Santner, 81114. Chicago, IL: University of Chicago Press. 
Rencana Strategis Badan Ekonomi Kreatif 2015-2019. Laporan dari website official Badan Ekonomi Kreatif Indonesia. The report can be accessed on http://www.bekraf.go.id/pustaka/page/35-rencana-strategisbadan-ekonomi-kreatif-2015-2019, accessed on 14 April 2019, pp. 19

Schumpeter, J. A. 1934. Theory in economic development. Cambridge, MA: Harvard University Press.

Star, Susan Leigh and James R. Griesemer. 1989. 'Institutional ecology, "translations" and boundary objects: Amateurs and professionals in Berkeley's Museum of vertebrate zoology.' Journal of Social Studies of Science, 19, 3 (1989), pp. 387-420. London: SAGE Journals.

UNESCO and Global Alliance for Cultural Diversity, Understanding creative industries: Cultural statistics for public policy making. 2006. Paris: UNESCO. (http:// portal.unesco.org/culture/en/ev.phpURL_ID=30297\&URL_DO=DO_TOPIC\&URL_SECTION=201.html). Accessed on 13 April 2019.

Verlag, Fischer. 2006. Max Horkheimer and Theodor W. Adorno, Dialektik der Aufklärung: Philosophische Fragmente. Frankfurt am Main: Frankfurt University Press, 128-76. 